\section{REFLEKSI HUKUM}

Jurnal Ilmu Hukum
p-ISSN 2541-4984 | e-ISSN 2541-5417

Volume 5 Nomor 1, Oktober 2020, Halaman 85-104

DOI: https://doi.org/10.24246/jrh.2020.v5.i1.p85-104

Open access at: http:// ejournal.uksw.edu/refleksihukum

Penerbit: Fakultas Hukum Universitas Kristen Satya Wacana

\title{
IMPLIKASI KEPPRES NO.12 TAHUN 2020 PADA PERUSAHAAN PEMBIAYAAN
}

\author{
Marhaeni Ria Siombo dan Emmanuel Ariananto Waluyo Adi \\ Fakultas Hukum Unika Atma Jaya Jakarta dan Kedeputian Bidang Kemaritiman dan \\ Investasi, Sekretariat Kabinet RI \\ Korespondensi: : eadiwaluyo@gmail.com
}

Naskah diterima: 25 Juni 2020|Direvisi: 18 September 2020|Disetujui: 30 Oktober 2020

\begin{abstract}
Abstrak
Perjanjian berisi tentang hak dan kewajiban para pihak dalam melakukan prestasinya masing-masing. Jika salah satu pihak tidak melakukan prestasi maka dianggap melakukan wanprestasi. Namun, ada excuse sebagaimana diatur dalam Pasal 1245 KUHPerdata. Wabah Covid-19 ditetapkan sebagai bencana nasional non-alam sebagaimana ditetapkan dalam Keppres No. 12 Tahun 2020, sangat berdampak luas termasuk lingkup perusahaan pembiayaan, yang mengakibatkan banyak debitur mengalami gagal bayar. Subtansi pengaturan dalam Keppres No.12 Tahun 2020 relevan dengan Pasal 1244 dan Pasal 1245 KUHPerdata. Sehingga diketahui bahwa debitur yang mengalami gagal bayar karena kondisi yang disebabkan oleh Covid-19 bukan merupakan wanprestasi. Namun demikian, itikad baik (Pasal 1338 ayat 3) dan prinsip kepatutan (Pasal 1339) KUHPerdata, harus mendasari penerapan Pasal 1245. Implikasi ditetapkannya Keppres No. 12 Tahun 2020 sudah selayaknya para debitur yang gagal bayar mendapatkan relaksasi, keringanan pembayaran dengan membebaskan dari pembayaran bunga, sebagaimana bunyi pasal 1245 KUHPerdata.
\end{abstract}

Kata kunci: Debitur; Perusahaan Pembiayaan; Keppres No. 12 Tahun 2020; Force Majeure.

\begin{abstract}
The agreement contains the rights and obligations of the parties in carrying out their respective achievements, if they do not make an achievement then it is considered to have committed default. But there is an excuse as regulated in article 1245 of the Civil Code. The Covid-19 outbreak is designated as a non-natural national disaster (Presidential Decree No.12 of 2020), has a very broad impact including the scope of financing companies which resulted in many debtors experiencing defaults. Presidential Decree No.12 of 2020 is relevant to article 1244 and article 1245 of the Civil Code. Therefore it is not a category of default. However, good faith (Article 1338 paragraph 3) and the principle of appropriateness (Article 1339) of the Civil Code must underlie the application of Article 1245. The impact of the stipulation of Presidential Decree No. 12 of 2020 is that debtors who failed to pay should receive relaxation, payment relief by exempting from interest payment, as stated in Article 1245 of the Civil Code.
\end{abstract}

Keywords: Financing Company; Debtors; Force Majeure. 


\section{PENDAHULUAN}

Dunia saat ini tengah menghadapi wabah penyakit Corona Virus Disease 2019 (Covid-19) yang menyebabkan adanya kebijakan physical distancing atau menjaga jarak fisik sebagai cara untuk menghindari penyebaran virus corona lebih luas. Kondisi tersebut mempengaruhi berbagai sektor dan untuk mengatasi peningkatan dampak negatif Covid-19. Khususnya di sektor ekonomi, pemerintah mengeluarkan kebijakankebijakan terkait yaitu Keputusan Presiden Nomor 12 Tahun 2020 Tentang Penetapan Bencana NonAlam Penyebaran Corona Virus Diseases 2019 Sebagai Bencana Nasional (selanjutnya disebut Keppres No. 12 Tahun 2020). Penetapan pemerintah tersebut menginformasikan bahwa Covid-19 telah melanda dan berdampak di seluruh wilayah Indonesia. Wadah Covid-19 berdampak dan mempengaruhi berbagai sektor terutama sektor ekonomi, karena itu dinyatakan sebagai bencana nasional non-alam. Pemerintah menetapkan kebijakan untuk mencegah meluasnya penularan Covid-19, yang kemudian membawah akibat pada berbagai sektor terutama sektor ekonomi. Pembatasan Sosial Berskala Besar (PSBB) merupakan pembatasan kegiatan tertentu penduduk dalam suatu wilayah, untuk menghindari terjadinya kerumunan atau interaksi jarak dekat, untuk mencegah terkontaminasi dan penyebaran virus. Kebijakan ini berdampak pada pengurangan tenaga kerja di pabrik-pabrik bahkan penutupan sementara waktu, pasar-pasar menjadi sepi bahkan tutup, hotel kehilangan penghuni, go-car/go-jek tidak mendapatkan customer, PHK dan/atau karyawan dirumahkan. Perusahaan pembiayaan khususnya pembiayaan leasing, yang konsumennya pada umumnya ekonomi menengah ke bawah mengalami gagal bayar. Secara hukum peristiwa 'gagal bayar' adalah wanprestasi. Hal tersebut dapat menjadi sebab putusnya perjanjian.

Keppres No. 12 Tahun 2020, membantu pihak kreditur dan debitur lingkup perusahaan pembiayaan dalam mempertimbangkan dan memutuskan permasalahan berkaitan dengan perjanjian yang telah disepakati para pihak yang dibuat sebelum terjadinya wabah Covid-19. Kebijakan PSBB mengakibatkan ruang gerak berusaha para pedagang, pengendara moda transportasi online dan pedagang kecil lain yang menjadi debitur perusahaan pembiayaan c.q. leasing dan/atau pembiayaan konsumen menjadi tidak ada pemasukannya. Apakah Keppres No. 12 Tahun 2020 dapat dijadikan acuan adanya situasi dan kondisi obyektif yang bisa menjadi alasan pemaaf (excuse) tidak terlaksananya perjanjian? Sebagai contoh di Sumatera Utara, tukang ojek dan sopir angkot mengalami penurunan penghasilan sampai 40 persen. ${ }^{1}$ Banyak diantara mereka yang berada dalam ketidakmampuan membayar, ketidakmampuan melaku-kan kewajibannya. Sementara untuk membayar kewajibannya pada peru-sahaan pembiayaan berasal dari pemasukan harian mereka. Dapatkah mereka dikategorikan wanprestasi? Apakah Keppres

Redaksi WE Online, 'Dampak Corona, Jokowi: Pendapatan Tukang Ojek Turun 40 Persen' (Warta Ekonomi, 24 Maret 2020) <https://www.wartaekonomi.co.id/read277916/> diakses 20 Juni 2020 
No. 12 Tahun 2020 relevan dengan Pasal 1245 KUHPerdata, bahwa gagal bayar debitur karena adanya kejadian di luar kesalahan debitur? Apakah gagal bayar debitur sebagai akibat dampak wabah Covid-19 dimana pemerintah mengeluarkan kebijakan pembatasan sosial berskala besar, yang kemudian penetapan penyebaran Covid-19 sebagai bencana nasional non-alam?. Hal-hal tersebut yang akan diuraikan dalam tulisan ini.

\section{PEMBAHASAN}

Lembaga keuangan dalam praktek terdiri atas 2 (dua) yaitu 1) lembaga keuangan bank; 2) lembaga keuangan non-bank. Lembaga pembiayaan kategori lembaga keuangan non-bank. Ruang lingkup lembaga pembiayaan adalah: a) Perusahaan pembiayaan, b) Pembiayaan modal ventura dan c) Pembiayaan infrastruktur. ${ }^{2}$ Perusahaan pembiayaan melakukan kegiatan pembiayaan yaitu: leasing, pembiayaan konsumen, factoring dan kartu kredit. Dalam tulisan ini lebih menyoroti perjanjian pembiayaan lingkup perusahaan pembiayaan khususnya pada skim leasing. Pembiayaan yang dilakukan pada skim Leasing adalah pembiayaan yang diberikan kreditur (lessor) untuk keperluan barang modal yang digunakan debitur (lease) dalam berusaha. Konsumen (debitur=lease) berkewajiban membayar cicilan kepada kreditur (lessor), berasal dari barang modal yang digunakan konsumen/debitur/ lease berusaha. Misalnya penjual sayuran di pasar atau tukang ojek (gocar, go-jek dll) kendaraan yang digunakan adalah barang modal yang berasal dari pembiayaan leasing. Dengan adanya beberapa kebijakan pe- merintah dalam mengatasi meluasnya dampak, seperti PSBB telah mengakibatkan debitur pada perusahaan leasing kesulitan menjalankan usahanya. Hal ini berpotensi gagal bayar, ketidakmampuan dalam melaksanakan kewajibannya. Permasalahannya adalah apakah konsumen/debitur/ lease dapat dikategorikan telah melakukan wanprestasi?

Untuk kondisi saat ini yang paling banyak terkena dampak Covid19 dan perlu mendapatkan relaksasi/ keringanan pembayaran adalah debitur dari skim leasing. Sebagaimana diketahui bahwa sejarah munculnya perusahaan pembiayaan karena desakan kebutuhan masyarakat yang tidak dapat diakomodir oleh lembaga keuangan bank. Bank menetapkan syarat-syarat yang ketat untuk dapat mencairkan pinjaman kredit bagi masyarakat, misalnya harus ada jaminan, yang sulit dipenuhi oleh sebagian masyarakat yang memiliki keinginan dan kemampuan berusaha tetapi tidak memiliki jaminan. Oleh karena itu bertumbuh pesatlah perusahaan pembiayaan yang lebih fleksibel dalam syarat-syarat, antara lain tidak mengsyaratkan adanya jaminan, barang modal itulah yang menjadi jaminan. Leasing pembiayaan dilakukan untuk barang modal, yang digunakan oleh lease (debitur) menjalankan usahanya dan sebagai sumber utama membayar kewajiban piutangnya kepada kreditur. Kelompok masyarakat yang menjadi debitur dari perusahaan pembiayaan (khususnya leasing), mayoritas adalah mereka dalam kelompok ekonomi menengah ke bawah, seperti pengemudi moda transportasi online (driver gojek/grab dll), para tukang sayur, pemilik

\footnotetext{
2 Peraturan Presiden Nomor 9 Tahun 2009 tentang Lembaga Pembiayaan.
} 
warung sederhana, tukang cukur rambut, dan pedagang-pedagang kecil lain yang butuh modal untuk menjalankan usahanya. Pada dasarnya lingkup perusahaan pembiayaan dalam hal ini sewa guna usaha (leasing) dan pembiayaan konsumen, sudah lama tumbuh dalam masyarakat tradisional. Bentuk-bentuk pinjaman modal atau untuk konsumtif yang didasarkan atas kepercayaan. Setelah diatur oleh pemerintah maka lebih terkontrol pelaksanaannya terutama dalam menerapkan asas keseimbangan dan keadilan dalam perjanjian. Hubungan kreditur (pemilik modal) dan debitur (mereka yang membutuhkan) harus berkeseimbangan dan berkeadilan. Praktekpraktek sistem 'ijon' yang banyak terjadi pada masyarakat tradisional kala itu lebih banyak merugikan debitur, harus dihindari.

\section{Perusahaan Pembiayaan}

Di Indonesia saat ini perusahaan pembiayaan berkembang pesat. Perusahaan pembiayaan merupakan salah satu dari lembaga pembiayaan. Lembaga pembiayaan terdiri atas 3 (tiga) yaitu; Perusahaan Pembiayaan, Modal Ventura dan Pembiayaan Infrastruktur. Lembaga pembiayaan merupakan lembaga keuangan non bank, yang tidak tunduk pada undangundang perbankan dan berbeda dengan lembaga keuangan bank. Jika lembaga keuangan bank dapat mengumpulkan dana langsung dari masyarakat berupa saving atau tabungan, maka lembaga keuangan non bank, di larang untuk mengumpulkan dana langsung dari masyarakat. Bank menerapkan syarat-syarat yang ketat untuk dapat memberikan pencairan kredit, karena dana yang dipakai untuk memberikan kredit kepada masyarakat antara lain adalah adalah dana (uang) dari semua orang yang menyimpan uang di bank dalam bentuk tabungan, selain modal bank itu sendiri. Oleh karena itu memerlukan pengelolaan yang ketat. Salah satu syarat utama adalah wajib memiliki jaminan, untuk mendapatkan bantuan kredit perbankan. Lembaga keuangan non bank khususnya lingkup perusahaan pembiayaan yang akan menjadi fokus pembahasan dalam tulisan ini, di larang untuk mengumpulkan dana langsung dari masyarakat dan dalam mencairkan kredit kepada masyarakat tidak dipersyaratkan untuk memberikan jaminan, sebagaimana syarat yang diberikan lembaga keuangan bank. Oleh karena itu di awal pertumbuhannya, para pengguna/debitur perusahaan pembiayaan, adalah masyarakat yang membutuhkan bantuan modal untuk menjalankan usahanya tetapi tidak memiliki jaminan. Tak heran jika perusahaan pembiayaan bertumbuh pesat, dikenal oleh masyarakat, karena kemudahan dalam mendapatkan bantuan modal. Pengguna perusahaan pembiayaan pada umumnya berasal dari kalangan ekonomi menengah ke bawah, terutama para pedagang kecil di pasar-pasar yang membutuhkan modal usaha atau membutuhkan kendaraan untuk mengangkut sayuran, pekerja moda transportasi online yang mendapatkan kendaraan motor/mobil dari perusahaan pembiayaan, dan menggunakan kendaraannya sebagai modal untuk mencari nafkah sekaligus membayar cicilan, dan lain-lain. Oleh karena itu perputaran uang lingkup perusahaan pembiayaan cukup besar, dan sangat membantu memberikan peluang usaha dan pekerjaan, yang sekaligus secara tidak langsung 
membantu program pemerintah dalam menciptakan lapangan kerja.

Ruang Lingkup perusahaan pembiayaan sebagaimana diatur dalam Perpres No. 9 Tahun 2009 tentang Lembaga Pembiayaan adalah: 1) Leasing atau Sewa Guna usaha (pembiayaan yang diberikan kepada debitur untuk keperluan barang modal); 2) Pembiayaan Konsumen (pembiayaan yang diberikan untuk kebutuhan konsumerisme); 3) Anjak Piutang atau Factoring (pembiayaan dalam bentuk pembelian piutang (penerima pengalihan piutang) dagang jangka pendek suatu perusahaan) dan 4) Kartu Kredit (alat pembayaran pengganti uang tunai). Bisnis lingkup perusahaan pembiayaan dikenal dengan bisnis 'multifinance', yang tidak ada pengaturannya dalam KUHPerdata, yang dasar hukum secara substansi adalah kebebasan berkontrak yang tercantum dalam pasal 1338 KUHPerdata.

\section{Prestasi dan Wanprestasi Dalam Perjanjian}

Hubungan hukum antara perusahaan pembiayaan (kreditur) sebagai pemberi pinjaman modal kepada konsumen (penerima pinjaman modal usaha atau disebut debitur) terjadi karena adanya kesepakatan diantara para pihak, melalui perjanjian/kontrak baku, yang dibuat oleh kreditur (perusahaan pembiayaan pemberi bantuan modal) dan dengan persetujuan atau kesepakatan dari pihak konsumen atau debitur (penerima pinjaman bantuan barang modal usaha). Perjanjian adalah kesepakatan atau persetujuan para pihak (kreditur dan debitur) yang berisi tentang hak dan kewajiban masing-masing pihak (prestasi) terhadap apa yang menjadi obyek perjanjian. Tujuan diadakan perjanjian yaitu hasil akhir yang diperoleh pihak-pihak berupa pemanfaatan, penikmataan dan pemilikan benda atau hak kebendaan sebagai pemenuhan kebutuhan pihak-pihak. ${ }^{3}$ Tujuan dari sebuah kontrak atau perjanjian adalah mewujudkan atau menciptakan kepastian hukum dan keadilan baik bagi para pihak yang membuatnya maupun bagi pihak ketiga oleh karena itu sebuah kontrak atau perjanjian haruslah dibuat sesuai dengan kaidah-kaidah hukum kontrak atau perjanjian atau sesuai dengan hukum yang berlaku. Prestasi menurut Pasal 1234 KUHPerdata terdiri atas: memberikan sesuatu, berbuat sesuatu, atau tidak berbuat sesuatu. Wujud prestasi dapat berupa: 1) barang, yang dilakukan dengan cara menyerahkan; 2) jasa (tenaga atau keahlian), dilakukan dengan cara berbuat sesuatu; dan 3) tidak berbuat sesuatu, dengan cara tidak berbuat sesuatu. 4

Pada lingkup perjanjian pembiayaan prestasi kreditur menyerahkan barang dan kewajiban debitur yang merupakan prestasi yang harus dilakukan adalah melakukan pembayaran. Ada interaksi hak dan kewajiban yang dituangkan tertulis dalam format baku yang saling disetujui sebelum prestasi dilaksanakan. Perjanjian pembiayaan merupakan hubungan kotraktual antara kreditur dan debitur, yang dituangkan dalam model perjanjian baku yang dibuat oleh kreditur, dan debitur

\footnotetext{
3 Ahmad Yusuf Sutardjo, 'Akibat Hukum Debitur Wanprestasi Pada Perjanjian Pembiayaan Konsumen' (2018) 6 (1) Privat Law 97.

$4 \quad$ Ahmadi Miru, Hukum Perikatan (Rajawali Pers 2014) 122.
} 
dipersilahkan untuk mempelajari yang jika setuju dengan klausul yang tertulis tersebut kemudian melakukan persetujuan dengan menandatangani perjanjian/kontrak tersebut, setelah itu para pihak terikat untuk melaksanakan hak dan kewajibannya. Perjanjian atau kontrak merupakan sebuah cara mengikat para pihak (kreditur dan debitur atau lessor dan lease) untuk menjamin bahwa para pihak akan memenuhi prestasinya atau janjinya. Perjanjian yang dibuat secara sah artinya sudah memenuhi syarat sahnya suatu perjanjian akan mengikat sebagaimana mengikatnya undang-undang (Pasal 1338 KUHPerdata atas asas pacta sunt servanda). Pembuat undang-undang memberikan pembatasan jika suatu peristiwa atau keadaan yang terjadi di luar salahnya para pihak, suatu keadaan yang tidak di duga sebelumnya, dapat menjadi alasan pemaaf untuk tidak terlaksananya kewajiban. Alasan pemaaf ini khusus untuk dapat dibebaskan dari pembayaran bunga, bukan hutang pokok, sebagaimana tercantum dalam Pasal 1245 KUHPerdata.

Pada skim leasing obyek perjanjian adalah barang yang dijadikan modal usaha para tukang ojek, sopir gocar/grabcar yaitu kendaraan bermotor, motor atau mobil. Secara hukum jika salah satu pihak tidak melaksanakan prestasi sebagaimana yang sudah disepakati maka dikategorikan sebagai wanprestasi atau tidak melakukan prestasi. Wanprestasi karena tidak melaksanakan kewajibannya atau tidak melakukan prestasi sebagaimana yang sudah disepakati, karena sengaja dan/atau lalai tidak melakukan prestasinya. Menurut hukum di hukum untuk membayar biaya, rugi dan bunga, sebagaimana diatur dalam Pasal 1239 s.d 1242 KUHPerdata. Namun demikian terhadap situasi yang tak terduga terjadi yang menyebabkan salah satu pihak tidak dapat melakukan prestasinya, telah diatur dalam pasal 1244 dan 1245 KUHPerdata. Ada 3 (tiga) unsur yang harus dipenuhi untuk memenuhi syarat keadaan memaksa, yaitu: 1) tidak memenuhi pretasi; 2) ada sebab yang terletak diluar kesalahan debitur dan 3) faktor penyebab tidak dapat di duga dan tidak dapat dipertanggungjawabkan kepada debitur. ${ }^{5}$ Untuk bisa dikategorikan bahwa gagal bayar dari debitur bukan salahnya, maka debitur harus bisa membuktikan 3 (tiga) syarat, yaitu: 1) ia tidak bersalah; 2) ia tidak dapat memenuhi kewajibannya secara lain; dan 3) ia tidak menanggung resiko. ${ }^{6}$

Prinsip iktikad baik menghendaki adanya pelaksanaan perjanjian secara layak dan patut, artinya memperhatikan prinsip goodfaith. Itikad baik harus ada pada para pihak, kreditur dan debitur, walaupun posisi diantara mereka tidak sama, apalagi perjanjian/kontrak baku dibuat oleh pihak kreditur. Asas itikad baik merupakan salah satu asas yang dikenal dalam hukum perjanjian/hukum kontrak, yang memiliki dua makna. Pertama adalah makna subyektif yang tertuju pada makna kejujuran dan makna yang kedua adalah tertuju pada kepatutan dan keadilan. Pasal 1338 ayat (3) menyatakan bahwa kontrak atau perjanjian harus dilak-

Rosa Agustina dkk, Hukum Perikatan (Pustaka Larasan 2012) 5.

Mariam Darus Badrulzaman, KUH Perdata BUKU III, Hukum Perikatan dengan Penjelasan (Alumni 2006) 35. 
sanakan dengan itikad baik. Pasal 1339 KUHPerdata menyatakan bahwa suatu perjanjian tidak hanya mengikat untuk hal-hal yang dengan tegas dinyatakan di dalamnya, tetapi juga untuk segala sesuatu yang menurut sifat perjanjian, diharuskan oleh kepatutan, kebiasaan atau undangundang. Dalam praktek seringkali kepatutan digunakan bersamaan dengan itikad baik, keduanya merupakan nilai moral yang mengandung kejujuran dalam berkontrak, yang merupakan makna dasar dari keadilan itu sendiri. Begitu pentingnya itikad baik sehingga dalam perundingan atau kontrak antara para pihak, kedua pihak akan berhadapan dengan suatu hubungan khusus yang dikuasai oleh itikad baik dan hubungan khusus ini berakibat bahwa kedua pihak harus bertindak dengan mengingat atau mempertimbangakan kepentingan pihak yang lain. Dengan demikian penggunaan perjanjian baku lingkup perusahaan pembiayaan tidak akan menimbulkan persoalan jika terjadi halhal di luar dugaan sebagaimana covid19 yang menyebabkan banyak debitur mengalami gagal bayar.

Oleh karena itu adalah tidak layak dan patut apabila perjanjian tetap dituntut pelaksanaannya dalam situasi dan kondisi yang didukung oleh pernyataan pemerintah bahwa Covid-19 adalah bencana nasional non-alam. Pihak yang dirugikan berhak menuntut penyesuaian syaratsyarat kontrak atau perjanjian guna menyesuaikan dengan keadaan yang baru. Jika terdapat perbedaan pendapat diantara kedua pihak maka mekanisme penyelesaian sengketa menggariskan kepada para pihak untuk mengedepankan musyawarah diantara para pihak yang bersengketa. Musyawarah menjadi prosedur yang sesuai dalam penanganan sengketa, karena selain waktu dan biaya penyelesaian sengketa yang murah, juga menghasilkan win-win solution bagi para pihak. ${ }^{7}$

\section{Dampak Covid-19 pada Sewa Guna Usaha (Leasing) dan Pembiayaan Konsumen}

Sewa Guna Usaha yang lebih dikenal masyarakat dengan istilah 'leasing' adalah kegiatan pembiayaan dalam bentuk penyediaan modal baik dengan hak opsi maupun tanpa hak opsi, dengan bentuk pembayaran angsuran. Leasing tidak dikenal dalam KUHPerdata. Leasing merupakan bentuk perjanjian antara sewa menyewa dan jual beli. Dasar hukum secara substantif adalah pasal 1338 KUHPerdata tentang kebebasan berkontrak. Bahwa para pihak bebas untuk melakukan hubungan hukum dan menentukan model hubungan perikatan diantara mereka, sepanjang itu memenuhi syarat sah nya suatu perjanjian sebagaimana disebutkan dalam Pasal 1320 KUHPerdata. Leasing tumbuh dalam praktek bisnis yang terjadi dalam masyarakat. Dalam melakukan kegiatan usaha, suatu perusahaan memerlukan barang modal untuk menjalankan usahanya, yang seringkali sulit diwujudkan karena tidak adanya dana tunai untuk membelinya. Begitupun yang banyak terjadi dengan usaha skala kecil atau usaha yang dilakukan perorangan, baik yang sudah jalan maupun yang ingin menjalankan usaha, tetapi tidak memiliki dana tunai dan /atau tidak

$7 \quad$ Sulasi Rongiyati, 'Perjanjian Penjaminan Kredit Antara UMKM dan Lembaga Penjaminan Berdasarkan UU No.1/2016 tentang Penjaminan' (2016) 7 (1) Jurnal Negara Hukum 11. 
memiliki jaminan. 8 Melalui skim leasing atau sewa guna usaha, perorangan maupun usaha kecil yang tidak memiliki jaminan tetapi punya kemampuan atau keinginan untuk menjalankan usaha, dimungkinkan mendapatkan modal usaha. Tak heran jika kemudian perusahaan pembiayaan secara khusus skim leasing bertumbuh pesat di kalangan ekonomi menengah ke bawah, terutama para pedagang kecil yang membutuhkan modal tetapi tidak memiliki jaminan. Jaminan merupakan syarat mencairkan kredit perbankan, sementara pada skim leasing modal utama adalah kepercayaan yang diejawantahkan dalam syarat-syarat. Melalui syaratsyarat yang diberikan oleh kreditur (lessor) yang harus dipenuhi lesse (debitur), supaya kreditur dapat mencairkan pinjaman modal kepada debitur (lesse). Jika syarat-syarat tersebut dipenuhi dan disetujui, menunjukkan bahwa lessor percaya kepada lease/debitur. Jaminannya hanya 'trust' dari lessor bahwa lease/debitur mampu bertanggungjawab melaksanakan kewajibannya. Tak heran jika bisnis leasing yang merupakan salah satu skim perusahaan pembiayaan, berkembang pesat.

Leasing diperuntukkan untuk pembiayaan atau pembelian barang modal usaha bagi debitur. Saat ini syarat-syarat tersebut dituangkan dalam perjanjian melalui format perjanjian baku dengan klausul baku, yang dibuat sepihak oleh kreditur, yang kemudian disetujui debitur. Doktrin normatif akan tetap menempatkan kebebasan berkontrak sebagai acuan, dengan menggunakan frase 'take it or leave it' sebagai standar, tetapi perlu diperhatikan tataran moral khususnya soal keadilan bagi debitur pada perusahaan pembiayaan yang umumnya menggunakan perjanjian baku. 9 Penggunaan perjanjian baku yang dibuat oleh salah satu pihak (kreditur) tidak menjadi masalah. Persoalannya adalah pada perumusan klausul yang merupakan pengejawantahan hak dan kewajiban masing-masing pihak, yang seringkali tidak berimbang. Dalam beberapa kasus klausul yang diterapkan menjadi kewajiban debitur lebih ketat dibanding kreditur. Hal ini misalnya dapat dilihat pada perjanjian baku yang tertera pada tiket pesawat terbang (dimasa lalu), dimana jika pesawat mengalami delay, penumpang tidak mendapat konpensasi, tetapi jika penumpang terlambat, tiket hangus. Tetapi kemudian dengan aturan baru, sudah mencantumkan konpensasi yang diberikan kepada penumpang jika pesawat delay. Sampai saat ini masih banyak ditemukan perjanjian baku dengan klausul yang tidak berimbang antara kreditur dan debitur, termasuk di lingkungan perusahaan pembiayaan. Dalam skim leasing hal ini bisa terjadi karena pihak lesse hanya menyetujui (menandatangani) saja format perjanjian yang disodorkan pihak kreditur (perusahaan pembiayaan). Dalam praktek pihak lesse (debitur) jarang atau sangat sedikit yang membaca secara utuh perjanjian baku yang disodorkan karena tak sabar mendapatkan barang modal yang diinginkannya. Sehingga tidak teliti untuk membaca, memahami dan mempertimbangkan apa yang menjadi kewajibannya sebagai-

\footnotetext{
$8 \quad$ Marhaeni Ria Siombo, Lembaga Pembiayaan Dalam Perspektif Hukum (Unika Atma Jaya 2018) 36.

$9 \quad$ Agus Sardjono, 'Karakteristik Kontrak-Kontrak Khusus Dalam Bidang Keperdataan' (Proceeding Konferensi Asosiasi Pengajar Hukum Keperdataan IV, Palembang, Oktober 2017).
} 
mana tertulis dalam perjanjian baku yang ditandatanganinya. Termasuk tidak teliti untuk memperkirakan halhal yang tak terduga bisa terjadi, misal karena sesuatu hal debitur gagal bayar.

Hubungan antara debitur dengan pihak kreditur pada umumnya kontraknya sudah dibuat secara standar oleh kreditur, sedangkan debitur tinggal menandatanganinya. Akibatnya seseorang menjadi terpaksa melakukan perjanjian, misalnya karena dalam keadaan butuh sekali akan barang modal sehingga menandatangani perjanjian dengan bunga tinggi, atau jika suatu perjanjian yang sudah dibuatkan konsepnya dan tinggal ditandatangani saja. Konsumen sendiri tidak mengerti isinya secara jelas, namun tetap disetujui karena yang dihadapi adalah lawan perikatannya yang memiliki posisi lebih tinggi, misalnya pengusaha besar, pejabat tinggi, dan sebagainya. 10 Dalam banyak kasus debitur tidak cermat dalam membaca klausul baku yang termuat dalam perjanjian baku. Sehingga ketika terjadi gagal bayar misalnya seperti pada peristiwa wabah Covid-19 dengan adanya penerapan PSBB yang berakibat pada tidak dapat memenuhi prestasi. Hal ini banyak menimpa para debitur kecil yang nafkah hidupnya sangat bergantung pada perputaran barang modal (seperti gojek, gocar, pedagang sayur, pedagang makanan, dll), yang jumlahnya tidak sedikit. Seketika terjadi kebijakan penerapan PSBB, pemasukan berkurang drastis, para go-jek, gocar, pedagang sayur, pedagang makanan, tidak dapat melaksanakan kewa- jibannya. Karena penetapan penyebaran Covid-19 sebagai bencana nasional non-alam, pemberlakuan PSBB semakin diperketat. Mall ditutup sampai batas yang ditentukan, hotel ditutup, pabrik ditutup dan/atau karyawan masuk dengan penerapan social distancing (artinya sebagian dirumahkan bahkan PHK), restoran ditutup, sekolah/ universitas ditutup, pasar dibatasi pengunjung dan/atau ditutup. Kebijakan Work From Home dan School From Home, semakin meningkatkan terjadinya 'gagal bayar' konsumen/debitur perusahaan pembiayaan cq leasing maupun pembiayaan konsumen. Karyawan pabrik yang terpaksa dirumahkan bahkan di PHK, sementara masih berlangsung kewajiban membayar cicilan pada perusahaan pembiayaan. Karyawan hotel, karyawan restoran, karyawan kantin sekolah, tukang sayur di pasar, para tukang ojek, yang tiba-tiba kehilangan pelanggan karena aktivitas yang dibatasi melalui penerapan social distancing dan PSBB, sementara kewajiban membayar cicilan barang modal (kendaraan atau lainnya) masih berlangsung. Mereka tidak siap dengan keadaan tersebut, seketika tidak memiliki kemampuan untuk melaksanakan kewajibannya. Apakah mereka wanprestasi? Siapa yang akan melindungi situasi dan kondisi yang mereka alami?

Skim leasing secara hukum memiliki ciri khas yang membedakannya dengan pembiayaan konsumen, yaitu pada saat perjanjian ditandatangani para pihak, barang berada dalam penguasaan debitur tetapi secara hukum pemilik barang masih

\footnotetext{
10 Agus Satory, Perjanjian Baku dan Perlindungan Konsumen Dalam Transaksi Bisnis Sektor Jasa Keuangan: Penerapan dan Implementasinya di Indonesia' (2015) 2 (2) Padjadjaran Jurnal Ilmu Hukum 276.
} 
berada pada kreditur (lessor). Oleh karena itu perjanjian fidusia pada leasing tidak diperlukan, karena barang tetap milik lessor sampai saat pelunasan. Pembiayaan Konsumen pembiayaan diberikan untuk keperluan konsumerisme, pembiayaan diberikan oleh kreditur bukan untuk barang modal, tetapi untuk kebutuhan konsumen. Berbeda dengan leasing, skim pembiayaan konsumen pada saat kedua pihak bersetuju atau menandatangani kontrak/perjanjian, pada saat itu barang berada dalam penguasaan debitur sekaligus pemilik barang. Kepemilikan barang berpindah dari kreditur kepada debitur. Inilah yang butuh perjanjian fidusia, karena secara hukum kepemilikan barang sudah berpindah kepada debitur. Pembiayaan konsumen, pembiayaan yang dilakukan untuk memenuhi kebutuhan konsumen akan bendabenda ysng diinginkan konsumen, bukan untuk barang modal. Oleh karena itu debitur pada skim pembiayaan konsumen, sudah mempersiapkan atau memperhitungkan pembayaran kewajibannya. Pembiayaan konsumen pada umumnya debitur dari masyarakat yang memiliki penghasilan tetap bulanan. Berbeda dengan skim leasing, dimana barang modal itulah yang digunakan untukan membayar kewajiban piutangnya setiap bulan. Era pandemi covid-19 prioritas relaksasi seharusnya pada debitur skim leasing, karena barang modal itulah yang digunakan untuk membayar cicilan angsuran yang menjadi kewajiban debitur.

Secara hukum putusnya perjanjian leasing dan/atau perjanjian pembiayaan konsumen, dapat terjadi karena 3 (tiga) hal, yaitu: a) konsensus, yang biasanya tercantum dalam perjanjian kapan berakhirnya perikatan diantara para pihak; b) wanprestasi; dan c) force majeur. Peristiwa force majeur sebagai alasan berakhirnya perjanjian, tidak mudah untuk menafsirkannya. Ada yang bersifat absolut dan ada force majeur yang bersifat relatif. Pada situasi dan kondisi saat ini, butuh kebijaksanaan dalam menafsirkan ketiga hal tersebut di atas tentang putusnya perjanjian. Khususnya yang berkaitan dengan penerapan asas keseimbangan, asas keadilan, itikad baik dan kepatutan sebagaimana tercantum dalam pasal 1338 dan pasal 1339 KUHPerdata. Pastinya bahwa Keppres No.12 tahun 2020 bukan penetapan tentang force majeur tetapi penetapan bahwa penyebaran covid-19 merupakan bencana nasional non-alam. Keppres No. 12 Tahun 2020 sangat dimungkinkan menjadi acuan dalam mempertimbangkan keberpihakan kepada debitur yang mengalami masalah karena kebijakan covid-19. Sehingga debitur tidak dikategorikan gagal bayar karena wanprestasi.

\section{Keppres No. 12 Tahun 2020 dan Force Majeur Dalam Perjanjian Pembiayaan}

Keppres No. 12 Tahun 2020 adalah tentang Penetapan Bencana Non-Alam Penyebaran Corona Virus Disease 2019 Sebagai Bencana Nasional. Keppres tersebut merupakan kebijakan Presiden Jokowi dalam menghadapi dampak dari wabah covid-19 yang sangat mempengaruhi perekonomian negara. Secara tidak langsung kegiatan bisnis yang dilakukan dengan perjanjian pembiayaan (leasing dan pembiayaan konsumen usaha) di bidang kendaraan bermotor telah menyumbang signifikan terhadap perekonomian Indonesia. Pada tahun 2019 penyaluran 
pembiayaan industri multifinance (perusahaan pembiayaan) meningkat 5,16\% menjadi Rp 436,26 triliun. Hal ini diikuti oleh peroleh laba bersih yang meningkat signifikan menjadi $\mathrm{Rp}$ 16,02 triliun pada tahun 2018 dimana pada tahun 2017 perolehan laba masih di angka Rp 13,26 triliun. ${ }^{11} \mathrm{Hal}$ tersebut menunjukkan bahwa perusahaan pembiayaan memberikan kontribusi yang besar dan sangat mempengaruhi jalannya perekonomian Indonesia saat ini.

Keppres No. 12 Tahun 2020 merupakan sebuah kebijakan pemerintah, yang dituangkan dalam bentuk aturan hukum (regulasi). Suatu aturan hukum memiliki akibat hukum yaitu: 1) Menimbulkan beberapa perubahan hak, kewajiban atau kewenangan yang ada; 2) Perubahan kedudukan hukum bagi seseorang atau objek yang ada; dan 3) Terdapat hak, kewajiban, kewenangan ataupun status tertentu yang ditetapkan. ${ }^{12} \mathrm{Ke}-$ bijakan pemerintah yang dikeluarkan berkaitan dengan pandemi Covid-19 (Peraturan Pemerintah Nomor 21 Tahun 2020 tentang Pembatasan Sosial Berskala Besar Dalam Rangka Percepatan Penanganan CoronaVirus Disease 2019 dan Keppres No. 12 Tahun 2020) yaitu subordinate legislations yang merupakan peraturan yang didelegasikan oleh undangundang (Undang-Undang Nomor 4 Tahun 1984 tentang Wabah Penyakit Menular, Undang-Undang Nomor 24 Tahun 2007 tentang Penanggulangan Bencana, Undang-Undang Nomor 6 Tahun 2018 tentang Kekarantinaan Kesehatan). Peraturan perundang- undangan tersebut termasuk ke dalam kategori allgemeene verbindende voorschriften atau peraturan yang mengikat untuk umum. 13 Pasal 100 Undang-Undang Republik Indonesia Nomor 12 Tahun 2011 tentang Pembentukan Peraturan PerundangUndangan menyebutkan "Semua Keputusan Presiden, Keputusan Menteri, Keputusan Gubernur, Keputusan Bupati/Walikota, atau keputusan pejabat lainnya yang sifatnya mengatur, yang sudah ada sebelum Undang-Undang ini berlaku, harus dimaknai sebagai peraturan, sepanjang tidak bertentangan dengan Undang-Undang ini".

Keppres No. 12 Tahun 2020 merupakan ketetapan pemerintah yang menegaskan bahwa pandemi Covid-19 adalah bencana nasional dengan kategori non-alam, bukan ketetapan tentang force majeure (keadaan memaksa). Force majeure termasuk resiko yang didalam praktek perjanjian para pihak menyerahkan beban resiko tersebut kepada pihak ketiga, dalam hal ini perusahaan asuransi. Klausula force majeur pada umumnya termuat dalam perjanjian, walaupun terbatas. Suatu perjanjian merupakan tuangan hak dan kewajiban dari para pihak, untuk melakukan prestasi. Adanya wabah Covid-19 yang antara lain berdampak pada gagalnya pelaksanaan prestasi dari perjanjian pembiayaan yang telah berjalan. Gagalnya pelaksanaan prestasi karena 'suatu hal tak terduga' sebagaimana dikuatkan dengan ketetapan pemerintah yang dituangkan dalam Keppres No.12 Tahun 2020, seharusnya tidak dapat dikategorikan wanprestasi. Keppres

\footnotetext{
11 Ferrika Sari, Herlina Kartika, 'Pendapatan industri multifinance capai Rp 107,78 triliun pada 2018' (Kontan, 28 Februari 2019) <https://keuangan.kontan.co.id/news/pendapatan-industrimultifinance-capai-rp-10778-triliun-pada-2018> diakses 19 Juni 2020.

12 Ridwan HR, Hukum Administrasi Negara (Raja Grafindo Persada 2014) 111.

13 Jimly Asshiddiqie, Pengantar Ilmu Hukum Tata Negara (Raja Grafindo Persada 2009) 152.
} 
No. 12 Tahun 2020 relevan dan memenuhi unsur 1244 dan pasal 1245 KUHPerdata. Pandemi Covid-19 merupakan suatu keadaan yang terjadi di luar kesengajaan debitur, suatu kondisi yang tidak diketahui saat perjanjian dibuat, suatu peristiwa yang tak terduga. Hal ini sangat relevan dengan Pasal $1245 \mathrm{KUH}-$ Perdata: "Tidaklah biaya rugi dan bunga, harus digantinya, apabila lantaran keadaan memaksa atau lantaran suatu kejadian tak disengaja si berhutang berhalangan memberikan atau berbuat sesuatu yang diwajibkan, atau lantaran hal-hal yang sama telah melakukan perbuatan yang terlarang". Bagaimana mengimplementasikan Pasal 1245 tersebut sehingga debitur tidak mengalami putus kontrak dan pandemi Covid-19 merupakan 'excuse' untuk diringankan (relaksasi) dalam melaksanakan kewajibannya. Force majeure pengaturannya di Indonesia terdapat dalam Pasal 1244 dan 1245 KUHPerdata, ketentuan tersebut lebih menekankan bagaimana tata cara penggantian biaya, rugi dan bunga, namun demikian dapat dijadikan acuan sebagai pengaturan force majeure. ${ }^{14}$

\section{Penerapan Prinsip Itikad Baik dan Kepatutan}

Dalam KUHPerdata terdapat prinsip-prinsip dalam melaksanakan perjanjian, yaitu prinsip keseimbangan yang berkeadilan, itikad baik dan kepatutan, supaya tercipta keadilan diantara para pihak yang saling berjanji. Prinsip keseimbangan dalam perjanjian baku yang pada umumnya terdapat dalam perjanjian pembiayaan, harus mendapatkan pengawasan dari Otoritas Jasa Keuangan. Supaya menghasilkan keadilan, karena keseimbangan para pihak hanya dapat terwujud apabila berada pada posisi yang sama kuat, yang seringkali menimbulkan ketidakadilan apabila salah satu pihak berada dalam posisi lemah. 15 Kegagalan pelaksanaan perjanjian oleh debitur memberikan hak gugat kepada kreditur untuk melaksanakan kepatuhan kesepakatan yang sudah dilakukan, yang meliputi: 1) pemenuhan prestasi; 2) putusnya perjanjian; dan 3) ganti rugi.

Debitur dapat mengajukan bantahan antara lain karena adanya force majeur (relatif) atau overmacht atau kejadian tak disengaja, debitur berada dalam situasi sulit yang menjadi sebab debitur tidak mampu melaksanakan kewajibannya. Suatu keadaan atau peristiwa yang dikategorikan sebagai force majeur atau overmacht membawa akibat hukum, sebagai berikut: 1) kreditor tidak dapat menuntut pemenuhan prestasi; 2) debitur tidak dapat lagi dinyatakan lalai; 3) debitur tidak wajib membayar ganti rugi; 4) risiko tidak beralih kepada debitur; 5) kreditor tidak dapat menuntut pembatalan perjanjian timbal balik; dan 6) perikatan dianggap gugur. ${ }^{16}$ Namun demikian untuk force majeur yang bersifat relatif sebagaimana wabah Covid-19, akan lebih cocok untuk diterapkan pasal 1245 KUHPerdata, dimana debitur dapat dibebaskan untuk tidak membayar bunga selama wabah covid-19 berlangsung. Terhadap hal-hal diatas terdapat beberapa bentuk kebijakan pemerintah melalui

\footnotetext{
14 Agri Chairunisa, 'Force Majeure Dalam Hukum Kontrak di Indonesia' (2015) 1 (1) Jurnal Veritas Et Justitia 140.

15 Agus Yuda Hernoko, Hukum Perjanjian (Prenadamedia 2010) 27.

$16 \quad$ Ibid, 272.
} 
OJK (Otoritas Jasa Keuangan) antara lain relaksasi kredit pada lembaga keuangan non-bank. Misalnya Peraturan Otoritas Jasa Keuangan Republik Indonesia Nomor 14/Pojk.05/2020 tentang Kebijakan Countercyclical Dampak Penyebaran Coronavirus Disease 2019 Bagi Lembaga Jasa Keuangan Non-bank (lingkup perusahaan pembiayaan. Relaksasi tersebut melalui beberapa pola antara lain restrukturisasi kredit/pembiayaan dengan cara: 1) penurunan suku bunga; 2) perpanjangan jangka waktu; 3) pengurangan tunggakan pokok; 4) pengurangan tunggakan bunga; 5) penambahan fasilitas $\mathrm{kredit} / \mathrm{pembi}$ ayaan; dan/atau 6) konversi kredit/pembiayaan menjadi Penyertaan Modal Sementara. Tetapi hal tersebut sangat bergantung pada penilaian yang patut atau kepatutan dan itikad baik kedua pihak untuk melihat Keppres No. 12 tahun 2020 sebagai alasan pemaaf tidak terlaksananya perjanjian.

\section{Covid-19 dan Force Majeure (Keadaan Memaksa)}

Force majeur atau Overmacht adalah suatu keadaan di luar kekuasaannya si berhutang, suatu keadaan yang timbul tidak terduga atau tidak dapat diketahui pada waktu perjanjian dibuat. Istilah force majeure dalam perjanjian sering juga disebut dengan istilah Overmacht, Act of God, Keadaan Memaksa, Keadaan Darurat, Keadaan Kahar, dan keadaan di luar kemampuan manusia. Force majeur terbagi 2, yaitu force majeur yang bersifat mutlak (absolut) yaitu si berhutang (debitur) sama sekali tidak dapat melaksanakan perjanjian. Force majeur yang bersifat relatif yaitu suatu keadaan dimana perjanjian masih dimungkinkan dilaksanakan, walau dengan pengorbanan/ usaha yg sangat besar. Tentang hal ini diatur dalam Pasal 1244 dan 1245 KUHPerdata.

Pasal 1245 KUHPerdata: "Tidaklah biaya rugi dan bunga, harus digantinya, apabila lantaran keadaan memaksa atau lantaran suatu kejadian tak disengaja si berhutang berhalangan memberikan atau berbuat sesuatu yang diwajibkan, atau lantaran hal-hal yang sama telah melakukan perbuatan yang terlarang". KUHPerdata mengatur tentang situasi keadaan memaksa (force majeur) yang menyebabkan si berhutang tidak dapat melaksanakan kewajibannya. Menurut Subekti 17 untuk dapat dikategorikan force majeur : 1) suatu keadaan di luar kekuasaan si berhutang; dan 2) keadaan yang timbul tersebut merupakan suatu keadaan yang tidak diketahui pada waktu perjanjian itu dibuat. Jika si berhutang berhasil dalam membuktikan adanya keadaan force majeur, baik penghukuman untuk memenuhi perjanjian maupun penghukuman untuk membayar penggantian kerugian. ${ }^{18}$

\section{Bagaimana Melakukan Penilaian Bahwa Suatu Keadaan Memenuhi Unsur Pasal 1245 KUHPerdata dan Hubungannya dengan Keppres No.12 Tahun 2020}

Force majeur dapat terjadi karena faktor eksternal dan faktor internal. Covid-19 yang melanda Indonesia yang berdasarkan Keppres No. 12 Tahun 2020, menyatakan bahwa penyebaran Covid-19 adalah Bencana Nasional Non-Alam, dapat dijadikan

17 Subekti, Pokok-Pokok Hukum Perdata (Intermasa 1985) 64.

18 Ibid. 
pintu masuk untuk menilai suatu situasi atau keadaan berada dalam force majeur atau terjadinya suatu peristiwa yang tak disengaja. Negara secara resmi sudah menyatakan bahwa Covid-19 merupakan bencana nasional. Dapat diartikan bahwa ada keadaan atau situasi penyebaran Covid-19 sudah melanda semua orang yang ada dalam negara tersebut. Keppres No. 12 Tahun 2020, dapat dijadikan dasar hukum kebijakan pemerintah dalam mencegah penyebaran Covid-19 semakin meluas. Dampak yang ditimbulkan dari Covid-19 mengancam semua orang. Keputusan Presiden tersebut kemudian disusul dengan peraturan yang dikeluarkan masing-masing daerah tentang PSBB, termasuk misalnya larangan para tukang ojek motor (gojek) dan go-car, untuk membawah penumpang, dibolehkan membawah barang saja. PSBB juga berdampak pada para pedagang yang menjadi debitur dari perusahaan pembiayaan, yang kemudian terpaksa tidak berjualan karena larangan adanya kerumunan orang. Karyawan pabrik yang terpaksa dirumahkan karena kebijakan social distancing diterapkan di pabrik. Pedagang kaki lima terpaksa tidak berjualan karena larangan PSBB, begitupun karyawan hotel, karyawan rumah makan yang terpaksa dirumahkan. Sementara kewajiban mereka pada perusahaan pembiayaan masih berjalan. Situasi tersebut berdampak pada gagal bayar yang menjadi kewajiban sebagaimana tertulis dalam kontrak / perjanjian yang telah disepakati. Dapat ditafsirkan bahwa gagal bayar debitur yang sumber pendapatannya berkurang bahkan kehilangan pendapatan karena kebijakan PSBB misal dapat dikategorikan force majeur relatif. Debitur dengan itikad baiknya harus mampu membuktikan bahwa gagal bayar tersebut dampak dari kebijakan diambil untuk mencegah penyebaran Covid-19. Hal ini merupakan kewenangan dari kreditur (perusahaan pembiayaan) dengan itikad baik dan mengingat asas keseimbangan yang berkeadilan dan kepatutan, untuk memutuskan apakah debitur tersebut gagal bayar bukan karena kesengajaan atau wanprestasi.

Ada istilah lain yang maknanya sama dengan force majeur, suatu keadaan tak terduga yaitu Hardship, dalam praktek sering diterjemahkan dengan suatu keadaan sulit. Perkembangan doktrin baru terkait dengan hambatan atau kendala pelaksanaan kontrak yang cukup penting dan mendasar adalah doktrin hardship yang diartikan suatu keadaan sulit, yang belum ada pengaturannya, oleh karena itu jika terjadi kasus-kasus terkait maka hakim memutus berdasarkan overmacht atau force majeur. ${ }^{19}$ Hardship merupakan bentuk pengecualian terhadap prinsip mengikatnya perjanjian (pacta sunt servanda). Doktrin ini tidak mensyaratkan adanya halangan dalam pelaksanan prestasi sehingga pelaksanan prestasi menjadi tidak mungkin (impossible), akan tetapi cukup apabila terjadi perubahan keadaan yang secara fundamental mengubah keseimbangan perjanjian baik disebabkan naiknya biaya pelaksanaan prestasi atau menurunnya nilai pelaksanaan prestasi. Keppres No. 12 Tahun 2020 yang kemudian meemicu semua daerah menerapkan kebijakan pencegahan penyebaran Covid-19 dengan melakukan PSBB. Hal ini menimbulkan suatu 
'keadaan yang sulit' bagi debitur perusahaan pembiayaan yang terkena dampak kebijakan sebagaimana tersebut di atas.

Dalam KUHPerdata hanya mengenal istilah force majeur atau overmacht. Dalam praktek istilah hardship dalam perjanjian ditempatkan sama dengan teori overmacht/ force majeure bersifat relatif. Bahwa terjadinya gagal bayar debitur atau ketidak mampuan memenuhi kewajiban atau melaksanakan prestasi akibat peristiwa yang tidak dapat diduga sebelumnya terjadi dan tidak berada dalam kendali pihak yang dirugikan saat penutupan kontrak. Seperti halnya hardship, pada force majeure relatif pemenuhan prestasi menjadi tertunda dan kontrak tidak putus. Pembatasan terhadap penerapan klausul hardship di Indonesia belum diatur dalam KUHPerdata Indonesia, namun ketentuan dasar seperti asas kebebasan berkontrak dan itikad baik masih dapat digunakan sebagai landasan dalam membuat dan melaksanakan perjanjian.

Keadaan memaksa yang bersifat mutlak (absolut) yaitu dalam halnya sama sekali tidak mungkin lagi melaksanakan perjanjiannya (misalnya (relative) yaitu berupa suatu keadaan di mana perjanjian masih dapat juga barangnya sudah hapus karena bencana alam), tetapi ada juga yang bersifat tak mutlak dilaksanakan tetapi dengan pengorbanan-pengorbanan yang sangat besar dari hak si berhutang (misalnya harga barang yang masih harus didatangkan oleh si penjual, sekonyong-konyong membumbung sangat tinggi atau dengan tiba-tiba oleh Pemerintah dikeluarkan suatu peraturan yang melarang dengan ancaman hukuman untuk mengeluarkan suatu macam barang dari suatu daerah menyebabkan si berhutang tidak dapat mengirimkan barangnya kepada si berpiutang). ${ }^{20}$ Dalam hal ini ada dua ukuran yaitu: 1) Subjektif, dilihat orang perorangan (misalnya si $\mathrm{X}$ takut dengan ular); 2) Objektif, dilihat pada umumnya (misalnya semua orang takut pada Tuhan).

Pihak yang harus membuktikan adanya keadaan memaksa adalah pihak debitur yang tidak dapat berprestasi dan yang harus dibuktikan adalah: 1) Bahwa debitur tidak mempunyai kesalahan atas timbulnya halangan prestasi; 2) Tidak memiliki pilihan lain; 3) Halangan itu tidak dapat terduga sebelumnya; 4) Debitur tidak menanggung risiko baik menurut ketentuan undang-undang maupun perjanjian. ${ }^{21}$

Menurut Mariam Darus Badrulzaman pihak yang memikul risiko bila terjadi keadaan memaksa dilihat dari pengaturan perjanjian pada KUHPerdata dalam hal ini pada perjanjian sepihak (pasal 1237 jo. 1444) yaitu bila terjadi risiko maka ditanggung kreditur. ${ }^{22}$ Pasal 1244 KUHPerdata. pasal ini berbunyi, "Debitur harus dihukum untuk mengganti biaya, kerugian dan bunga bila ia tak dapat membuktikan bahwa tidak dilaksanakannya perikatan itu atau tidak tepatnya waktu dalam melaksanakan perikatan itu disebabkan oleh sesuatu hal yang tak terduga, yang tak dapat dipertanggungkan kepadanya walaupun tidak ada itikad buruk kepada-

Subekti (n 12) 151.

Handri Raharjo, Hukum Perjanjian di Indonesia (Pustaka Yustisia 2009) 104.

Ibid., 106. 
nya." sementara di Pasal 1245 KUHPerdata menambahkan, bunyinya, "Tidak ada penggantian biaya, kerugian dan bunga bila karena keadaan memaksa atau karena hal yang terjadi secara kebetulan, debitur terhalang untuk memberikan atau berbuat sesuatu yang diwajibkan, atau melakukan suatu perbuatan yang terlarang baginya."

Wabah Covid-19 yang terjadi di seluruh dunia termasuk Indonesia, jika hal ini dikategorikan sebagai keadaan force majeur yang bersifat relatif dan sifatnya sementara, maka sesuai pasal 1245 KUHPerdata yang dapat dibebaskan adalah bunga, utang pokok tetap menjadi tanggung jawab debitur. Hal ini pun seharusnya tidak menjadi alasan untuk diputusnya perjanjian/kontrak, sebagaimana disebtkan dalam Pasal 1339 KUHPerdata berkaitan dengan kepatutan. $\mathrm{Pa}-$ sal 1245 KUHPerdata sebagaimana disebutkan diatas, jika debitur berada dalam situasi di luar salahnya sehingga berada dalam posisi tak mampu membayar atau gagal bayar, maka debitur dapat dibebaskan untuk membayar bunga. Sebagaimana dikemukakan di atas, bahwa norma itikad baik adalah salah satu sendi yang terpenting dalam pelaksanaan suatu perjanjian. ${ }^{23}$

\section{Implementasi Pasal 1245 KUH- Perdata dan Kebijakan Pemerintah bagi Debitur Gagal Bayar Karena Pandemi Covid-19}

Perusahaan pembiayaan secara hirarki berada dalam pengawasan dan pembinaan Otoritas Jasa Keuangan (OJK). OJK menyampaikan, sampai dengan 31 Maret 2020, terdapat 11.235 permohonan konsumen yang sudah mengajukan keringanan cicilan ke perusahaan pembiayaan. terdapat 138 perusahaan leasing yang berkomitmen menjalankan stimulus yang sudah diatur oleh OJK. Dari 138 perusahaan tersebut, sebanyak 99 perusahaan sudah memiliki kebijakan untuk melaksanakan restrukturisasi pembiyaan. Pemerintah sebagai pengambil kebijakan pencegahan penyebaran covid-19, termasuk yang menerapkan PSBB sekaligus sebagai regulator, kemudian menetapkan Keppres No. 12 Tahun 2020. Adanya Keppres No. 12 Tahun 2020, setidaknya merupakan pernyataan sekaligus pengumuman kepada publik di seluruh Indonesia, bahwa covid-19 merupakan bencana, yang dirasakan oleh semua orang. Terbitnya Keppres No. 12 Tahun 2020, sekaligus berfungsi secara tidak langsung sebagai 'pemberitahuan' untuk memberikan keringanan berkaitan dengan 'gagal bayar'. Bahwa telah memenuhi unsur pasal 1245 KUHPerdata. Keppres No. 12 Tahun 2020, kemudian diikuti oleh kebijakan pemerintah yang memberikan keringanan kepada masyarakat yang mengalami dampak langsung dari penerapan kebijakan pemerintah dalam mencegah penyebaran covid19. Oleh karena itu muncul kebijakan pemerintah untuk dapat melindungi pihak yang mengalami dampak dan 'gagal bayar' melalui keringanan (relaksasi) atas situasi dan kondisi yang terjadi di luar kesalahan mereka, yaitu adanya bencana nasional non-alam (sesuai Keppres No. 12 Tahun 2020). Relaksasi ini tidak bermaksud mencampuri asas kebebasan berkontrak tetapi himbauan adanya kebijaksana-

23 Nindyo Pramono, 'Problematika Putusan Hakim Dalam Perkara Pembatalan Perjanjian' (2010) 22 (2) Mimbar Hukum 226. 
an kreditur, dengan mengacu pada asas keseimbangan yang berkeadilan.

Pandemi Covid-19 suatu peristiwa yang tak dapa diduga sebelumnya, jika kemudian ditafsirkan bahwa hal tersebut kategori force majeur yang sifatnya relatif maka perlu dipertimbangkan untuk memberikan kesempatan kepada debitur perusahaan pembiayaan, dengan kebijaksanaan memberikan keringanan pembiayaan sehingga debitur tetap dapat menggunakan barang modal (untuk skim leasing) untuk berusaha melunasi hutangnya. Dengan melakukan beberapa hal berikut:

1) Memperpanjang jangka waktu angsuran pinjaman pokok, misalnya dari 24 kali menjadi 36 kali, dengan tanpa penghitungan bunga selama masa pandemi berlangsung. Artinya selama masa pandemi berlangsung, debitur dibebaskan dari pembayaran bunga, sebagaimana pasal 1245 KUHPerdata. Hal ini akan memperkecil jumlah angsuran yang harus dibayar setiap bulan, karena penambahan waktu angsuran; dan/atau

2) Melakukan penurunan suku bunga sampai pandemi berakhir.

Butir a dan $\mathrm{b}$ diatas tentunya dibutuhkan pembaharuan persyaratan yang tercantum dalam perjanjian pembiayaan.

Hal-hal di atas tentunya harus dilandaskan pada itikad baik dari kedua pihak. Jika betul sesuai fakta bahwa debitur karena kebijakan pemerintah untuk mencegah meluasnya wabah Covid-19 telah mengambil kebijakan yang berdampak pada sulitnya atau terbatasnya debitur dalam mengoperasikan barang modal dan ada itikad baik dari debitur untuk tetap akan melunasi hutangnya, maka cara-cara di atas cukup adil untuk diterapkan.

Asas kebebasan berkontrak sebagaimana tersebut dalam Pasal 1338 KUHPerdata, tetap menjadi acuan, jika dalam kontrak disebutkan jelas force majeur meliputi peristiwa pandemi (wabah penyakit) maka tidak akan mengalami masalah. Tetapi jika tidak disebutkan secara langsung lingkup force majeur dalam kontrak/ perjanjian maka dapat dilihat bahwa Pasal 1245 KUHPerdata sifatnya melengkapi perjanjian. Artinya jika para pihak tidak mengatur jelas dalam perjanjiannya maka pasal $1245 \mathrm{KUH}-$ Perdata dapat diberlakukan, kecuali para pihak secara tegas menyatakannya dalam perjanjian mereka bahwa wabah penyakit (pandemi) tidak termasuk lingkup force majeur maka apa yang pihak sepakati itulah yang dilakukan. Pasal 1245 KUHPerdata. "Semua pelaku usaha harus mematuhi, kalaupun ada keberatan dari sisi teknis hukum terkait hak dan kewajiban dalam kontrak, pihak tersebut tetap harus mengikuti upaya pembebasan semua pihak melalui force majeur"

\section{PENUTUP}

Keppres No. 12 Tahun 2020, dapat memenuhi unsur adanya suatu kejadian tak disengaja yang diatur dalam Pasal 1245 KUHPerdata. Dengan demikian debitur yang mengalami gagal bayar karena adanya kondisi yang disebabkan karena Covid-19, bukan kategori wanprestasi. Adanya perjanjian baku/kontrak baku, memiliki keterbatasan, terutama bagi debitur yang merupakan pihak yang membutuhkan, yang dalam prakteknya perjanjian dibuat oleh kreditur dan debitur 'hanya' menyetujuinya. 
Namun demikian kedua pihak harus dilandasi dengan itikad baik dan kepatutan yang memiliki kekuatan moral yang melandasi keadilan itu sendiri. Oleh karena itu jika terjadi peristiwa seperti adanya pandemiCovid-19, yang memunculkan kebijakan pembatasan sosial berskala besar (PSBB) untuk mencegah meluasnya wabah, berdampak pada debitur perusahaan pembiayaan yang gagal bayar. Gagal bayar tersebut mesti dilihat secara bijaksana dengan mempertimbangan itikad baik, kepatutan, asas keseimbangan dan keadilan. Sehingga ada relaksasi untuk meringankan debitur dalam melunasi hutangnya sebagaimana juga tertulis dalam pasal 1245 KUHPerdata. Force majeur suatu peristiwa yang tidak terduga, para pihak tidak mengetahui saat perjanjian dibuat. Pandemi covid19 yang dalam Keppres No. 12 Tahun 2020 ditetapkan sebagai Bencana Nasional Non-Alam, sangat relevan dengan pasal 1244 dan pasal 1245 KUHPerdata, adanya force majeur yang sifatnya relatif. Sehingga gagal bayar debitur tidak dapat dikategorikan dalam wanprestasi.

Peristiwa pandemi Covid-19 menjadi pembelajaran bahwa perjanjian yang dibuat oleh para pihak khususnya perjanjian baku yang dibuat oleh kreditur (perusahaan pembiayaan dengan pengawasan Otoritas Jasa Keuangan) semestinya mampu menjangkau segala kemungkinan yang akan terjadi di masa depan. Perjanjian baku harus berdasarkan itikad baik dan kepatutan dengan mempertimbangkan keseimbangan kepentingan dan keadilan, sehingga perlu mengantisipasi dengan memasukkan klausul yang berkeadilan.

\section{DAFTAR BACAAN}

\section{Buku}

Agustina R, dkk, Hukum Perikatan (Pustaka Larasan 2012).

Asshiddiqie J, Pengantar Ilmu Hukum Tata Negara (Raja Grafindo Persada 2009).

Badrulzaman MD, KUHPerdata BUKU III, Hukum Perikatan dengan Penjelasan (Alumni 2006).

Hernoko AY, Hukum Perjanjian (Prenadamedia 2010).

Miru A, Hukum Perikatan (Rajawali Pers 2014).

Raharjo H, Hukum Perjanjian di Indonesia (Pustaka Yustisia 2009).

Ridwan HR, Hukum Administrasi Negara (Raja Grafindo Persada 2014).

Siombo MR, Lembaga Pembiayaan Dalam Perspektif Hukum (Unika Atma Jaya 2018).

Subekti, Pokok-Pokok Hukum Perdata (Intermasa 1985).

\section{Artikel Jurnal}

Chairunisa A, 'Force Majeure Dalam Hukum Kontrak di Indonesia' (2015) 1 (1) Jurnal Veritas Et Justitia.

Pramono N, 'Problematika Putusan Hakim Dalam Perkara Pembatalan Perjanjian' (2010) 22 (2) Mimbar Hukum.

Rongiyati S, 'Perjanjian Penjaminan Kredit Antara UMKM dan Lembaga Penjaminan Berdasarkan UU No.1/2016 tentang Penjaminan' (2016) 7 (1) Jurnal Negara Hukum.

Sutardjo AY, 'Akibat Hukum Debitur Wanprestasi Pada Perjanjian Pembiayaan Konsumen' (2018) 6 (1) Privat Law.

Agus Satory, 'Perjanjian Baku dan Perlindungan Konsumen Dalam Transaksi Bisnis Sektor Jasa 
Keuangan: Penerapan dan Implementasinya di Indonesia' (2015) 2 (2) Padjadjaran Jurnal Ilmu Hukum.

\section{Konferensi}

Sardjono A, 'Karakteristik KontrakKontrak Khusus Dalam Bidang Keperdataan' (Proceeding Konferensi Asosiasi Pengajar Hukum Keperdataan IV, Palembang, Oktober 2017).

\section{Website}

Redaksi WE Online, 'Dampak Corona, Jokowi: Pendapatan Tukang Ojek Turun 40 Persen' (WE Online, 24 Maret 2020) <https://www. wartaekonomi.co.id/read277916 /> diakses 20 Juni 2020.

Sari $F$ dan Kartika $H$, 'Pendapatan Industri Multifinance Capai Rp 107,78 triliun pada 2018' (Kontan, 26 Februari 2019) $<$ https:/ / keuangan.kontan.co.id /news/pendapatan-industrimultifinance-capai-rp-10778triliun-pada-2018> diakses 19 Juni 2020.

\section{Peraturan Perundang-Undangan}

Kitab Undang-Undang Hukum Perdata.

Peraturan Pemerintah Nomor 21 Tahun 2020 tentang Pembatasan Sosial Berskala Besar dalam rangka Percepatan Penanganan Corona VirusDisease (COVID19)

Peraturan Presiden Nomor 9 Tahun 2009 tentang Lembaga Pembiayaan.

Keputusan Presiden Nomor 12 Tahun 2020 tentang Penetapan Penyebaran Corona Virus Disease 2019 (Covid-19) Sebagai Bencana Nasional Non-Alam. 